\title{
MPRA
}

Munich Personal RePEc Archive

Is government's help for unemployed people helpful for the society? An Empirical Study on Macro Data of Public Unemployment Spending in OECD Nations

DING, HONG

6 December 2012

Online at https://mpra.ub.uni-muenchen.de/43132/

MPRA Paper No. 43132, posted 31 Jan 2014 13:20 UTC 


\title{
Is government's help for unemployed people helpful for the society? An Empirical Study on Macro Data of Public Unemployment Spending in OECD Nations
}

\section{Hong Ding}

\begin{abstract}
Using panel data of public unemployment expenditure as a percentage of GDP of 34 OECD nations across year 1980-2010, I explore the effect of this ratio on three unemployment outcomes: total unemployment rate, long-term unemployment rate and youth unemployment, as well as labor participation rate and investment rate. After taking into account potential endogeneity of this ratio using Durbin-Wu-Hausman test, I find the data does not support the hypothesized aggregate demand effect of unemployment insurance (UI) expenditure in theory but gives strong support for hypothesized disincentive effect in theory. The estimates indicate that every percentage point increase in public unemployment welfare expenditure relative to GDP leads to 0.9 to 1.1 percentage point increase in total unemployment rate and 4.5 to 4.7 percentage point increase in long term unemployment rate. The distortionary effect of UI program on business is also verified by an estimate that every percentage point increase in this unemployment spending rate is associated with about 2.1 percentage point decrease in investment rate.
\end{abstract}

\section{Background}

This paper is an academic exploration of the claim in a Wall Street Journal article: Bernanke: Unemployment Benefits Don't Keep Jobless Rate High ${ }^{1}$. The claim of the chairman of Federal Reserve is that providing benefits to workers without a job likely doesn't contribute to the jobless rate or the high level of the long-term unemployed. According to this WSJ report,

\footnotetext{
${ }^{1}$ http://blogs.wsj.com/economics/2012/03/26/bernanke-unemployment-benefits-dont-keep-jobless-rate-high/
} 
Bernanke's remark was a response to questions at the annual conference of the National Association for Business Economics. The original quote of the Federal Reserve Chairman's answer is "I would not attribute the extent of long-term unemployment or the very high level of unemployment to unemployment insurance."

Whether the provision and generosity of unemployment insurance (UI) increases unemployment has been the subject of much research (See Holmlund (1998), Krueger \& Meyer (2002), and Fredriksson \& Holmlund (2006) for recent reviews of the literature). Theory generally predicts that UI has two offsetting effects on unemployment, as the following section elaborates, leaving the net impact of UI an empirical issue for investigation.

Most of previous studies on the relationship between UI and unemployment were based on micro data. The use of data over countries or regions, observed at different points in time, is presumably a more promising way to estimate the equilibrium effects of variations in UI benefit generosity. The prototypical US study in this vein (e.g. Katz \& Meyer, 1990) uses policy changes at the state level to identify the effects. However, this approach can be criticized because policy changes at the state level are endogenous with respect to the local business cycle, see for example Card \& Levine (2000) and Lalive \& Zweimüller (2004).

Card \& Levine (2000) used variations in the national UI rules to estimate the effects at the regional level. Hence, the estimates should not suffer from the potential policy endogeneity hampering studies using regional policy changes for identification. The evidence suggests that benefit generosity increases unemployment and the estimates are robust across alternative specifications. The magnitudes involved are rather substantial and appear to be relatively high compared to estimates available elsewhere in the literature. The estimates suggest that an increase in the (actual) replacement rate of 5 percentage points contributes to increasing unemployment by 25 percent.

However Valletta and Kuang (2010) find that the effect in the downturn since 2008 appears quite small compared with other determinants of the unemployment rate. Their analyses suggest that extended UI benefits account for about 0.4 percentage point of the nearly 6 percentage point increase in the national unemployment rate over the past few years. This paper drafted by Federal Reserve Bank of San Francisco seems to provide some evidence to support Chairman Bernanke's claim. 
Barro (2012) found that that UI benefit extensions (from 26 weeks to 99 weeks) raised the unemployment rate by 2.7 percentage point (from 6.8\% to 9.5\%). However, Rothstein (2011) finds that that UI benefit extensions (from 26 weeks to 99 weeks) raised the unemployment rate in early 2011 by only about $0.1-0.5$ percentage points, much less than is implied by previous analyses. Howell and Azizoglu (2011) used a survey of studies on unemployment insurance's effect on employment to conclude that that unemployed who collected UI did not find themselves out of work longer than those who didn't have unemployment benefits; and that unemployed workers did not search for work more or reduce their wage expectations once their benefits ran out.

This paper aims to investigate: 1) do the two effects of unemployment insurance (UI) on unemployment rate at macro level hold predicted by theory hold: aggregate demand effect and incentive effect? 2) What is the net effect of public unemployment spending as percentage of GDP (rather than duration of UI) on three unemployment measures: total unemployment rate, long-term unemployment rate and youth unemployment rate; 3) what is the magnitude of this effect based on panel data of OECD nations. The public unemployment spending rate is a better measure of the scale of overall governmental financial assistance to unemployed people than duration of UI when the study purpose is on macro effect of this entitlement program.

The variables used in this paper, data source and time coverage of each variable are presented in table 1. Table 2 presents descriptive statistics of the variables used in the paper. Table 3 shows the correlation between unemployment outcomes and the unemployment spending rate (unem_exp). The correlations between total unemployment rate/long term unemployment rate and unem_exp are positive and statistically significant but that between youth unemployment rate and unem_exp is not statistically significant, suggesting that public unemployment spending affects youth less than adult. This may be related to the fact that the level of UI benefits depends upon previous earnings so that the disincentive effect of UI is smaller for youth than senior workers. The correlation between working hours (hours) and unem_exp is negative and strongly significant, supporting disincentive effect of the theory explained below. Although the correlation between log of per capita GDP (logypc) and unem_exp supports the aggregate 
demand effect of the theory, that between household consumption relative to GDP goes against the theory.

\section{Theory}

In theory, an increase in unemployment insurance has two effects. First is the disincentive effects. The second is the aggregate demand effect, as claimed by Congressional Budget Office (CBO 2010) .

Suppose employment supply and employment demand ( $n^{s}$ and $n^{d}$, respectively) are given by:

(1) $n^{s}=\alpha_{0}+\alpha_{1} U I+\alpha_{2} w$

(2) $n^{d}=\beta_{0}+\beta_{1} U I+\beta_{2} w$

Where $U I$ is a measure of unemployment insurance payments, and $w$ is the wage rate. According to the theory, $\alpha_{1}<0, \alpha_{2}>0 ; \beta_{1}>0 ; \beta_{2}<0$. Hence, we are assuming some disincentive effects from UI, but stimulative effects from UI increasing consumption and hence demand for labor.

$\mathrm{CBO}(2012)$ supports these two effects, its explanation of (1) and (2) are (page 9):

- UI benefits increase incentives for workers who lose their job to look for work (by requiring them to do so in order to receive benefits) but reduce the incentives to accept a job offer.

- The UI system serves as an automatic economic stabilizer by supporting consumer spending when income falls, which in turn boosts aggregate economic activity.

Its overall conclusion on these two offsetting effects is "the positive impact of the additional UI benefits on the demand for goods and services - and thus on economic activity - has been significantly larger than the net impact on economic activity of the various other ways in which the increase in UI benefits has affected the economy (including greater incentives to search for a job and reduced incentives to accept a job offer). So it thinks that the effect of (2) is larger than (1). Specifically, it estimates that that the policy of increasing Aid to the Unemployed would add 8 to 19 cumulative years of full-time-equivalent employment in 2010 and 2011 per million 
dollars of total budgetary cost. $^{2}(\mathrm{CBO}$ (2010)). It also estimates that extending additional unemployment benefits, or even combined with paying health insurance premiums would raise output cumulatively between 2010 and 2015 by $\$ 0.70$ to $\$ 1.90$ per dollar of total budgetary cost. No detail about how this estimate was calculated was provided. To test whether these estimates hold, this paper tries to use macro panel data of 29 OECD countries to investigate the overall effects of public unemployment expenditure by government on three unemployment measures: total, long-term and youth unemployment rates, household consumption relative to GDP and per capita GDP.

CBO (2010) claimed that, "Households receiving unemployment benefits tend to spend the additional benefits quickly, making this option both timely and cost-effective in spurring economic activity and employment", so it is expected that household consumption as a percentage of GDP should rise due to this stimulative effect of UI and as a result so does to per capita income. CBO (2012) argues that UI benefits increase incentives for workers who lose their job to look for work because of eligibility requirement of UI but reduces the incentives to accept a job offer thus raising unemployment rate. CBO (2010) also admits that UI could dampen people's efforts to look for work. Actually both may be true. The net effect is, based on CBO's conclusion is the automatic stabilizer effect dominates incentive effect of UI. To test whether this conclusion has any empirical evidence to support is one motivation of this paper. Another aim of the paper is to investigate the long term effect of unemployment public expenditure in terms of long term unemployment rate, which is the proportion of people who have been unemployed for 12 months or more among all unemployed. This may be more policy interest for decision makers.

Since one eligibility requirement of UI program is claimant is looking for job and has not given up job hunting, it is expected unemployment welfare spending will increase labor participation rate although some applicants may not be sincerely looking for jobs. The effect of unem_exp on labor participation rate will also be investigated in this paper.

The theory on the two effects of UI only concerns the behavior of individuals. UI programs may also impact on the behavior of business because of increases in taxes required to pay for the

\footnotetext{
2 Policies for Increasing Economic Growth and Employment in 2010 and 2011, January 2010, CONGRESSIONAL BUDGET OFFICE, SECOND AND D STREETS, S.W., WASHINGTON, D.C. 20515, http://www.cbo.gov/sites/default/files/cbofiles/ftpdocs/108xx/doc10803/01-14-employment.pdf
} 
program. The possible effect of public unemployment welfare expenditure on business, particularly on investment rate will also be explored.

This paper will test two effects in theory first and then develop a full-fledged model on unemployment outcomes and labor participation rate with more control variables before testing the effect on overall investment rate of business.

\section{The Model and Estimation Approach}

\subsection{The model for testing two effects in theory}

The model for testing aggregate demand effect and incentive effect of UI is just a standard twoway fixed effect model implemented by LSDV (Least Square Dummy Variable) estimation or IV estimation for panel data, depending on significance of the statistic of Durbin-Wu-Hausman Endogeneity test after instrument variable (IV) strength test, as explained in details later.

To test the hypothesized disincentive effect of unem_exp, labor supply is proxied by hours (Average hours actually worked per person per year in employment), which is taken as response variable. The explanatory variables include wage growth rate (wageg, annual growth rate of labor compensation per labor unit) and labor productivity growth rate (labor_prodg). To test the hypothesized aggregate demand effect of unem_exp, two variables are used to represent change in aggregate demand: household consumption as a percentage of GDP (hh_consumr) and log of per capita GDP (logypc), the first of which is for testing if unem_exp has stimulating effect on consumption, as proposed in theory, the second of which is for testing if ultimately unem_exp can promote aggregate demand and income, which is hypothesized by theory and expected by CBO. The two variables hh_consumr and logypc are taken as dependent variable separately and they have the same set of independent variables: unem_exp, wageg, long_real_r(long real interest rate) and inflation, the last two of which may affect household's choice between consumption and saving.

Because the data is panel data, all regressions will include fixed effects of both country and year. The reason to choose fixed effect (FE) model rather than random effect (RE) model is for controlling unobservable time-invariant country heterogeneity and global time trend of technology despite the fact that RE estimator may have higher efficiency than FE estimator when unobservables are not correlated with included explanatory variables. 
The implementation of this two-way FE model is the classical approach of LSDV Regression : adding two sets of dummy variables for country and year, respectively to the OLS regression.

\subsection{Full model}

The specification of the full-fledged model is:

$$
y_{i t}=y_{i t-1} \alpha+\theta_{t}+x_{i t} \gamma+w_{i t} \delta+c_{i}+u_{i t} \quad \mathrm{t}=1,2, \ldots, \mathrm{T}
$$

where $y_{i t}$ is the unemployment rate (total, youth, or long-term unemployment) or labor participation rate (LPR)for country $\mathrm{i}$ at time $\mathrm{t}$.

$y_{i t-1}$ captures persistence of unemployment or LPR. As Bernal-Verdugo et. al. (2012) point out,

it is important to note there is high persistence of unemployment rates. According to their estimation results, a one percentage point increase in previous unemployment translates into a 0.83 percentage point higher unemployment in the current period, which can be dubbed as a "momentum" effect of pre-existing unemployment rate levels. OECD (2006) also indicates that a macroeconomic shock might not only raise current unemployment but, in addition, its effects might persist over time. In order to assess initial versus persistence effects of shocks, a dynamic version of the standard fixed effect (FE) model is needed. Following Wooldrige (2001, pp. 299), two-period and three-period lagged values of the response variable are used to instrument $y_{i t-1}$ to

make sure consistency of estimators in (3).

$x_{i t}$ is $1 \times 6$ vector and contains 6 observable explanatory variables which are assumed to be strictly exogenous, these six control variables included in the full model for unemployment rates and participation rate are: labor productivity growth rate (labor_prodg), percentage change in the terms of trade weighted by the trade openness of the country(dtot), inflation rate(inflation), long real interest rate (long_real_r, the nominal returns on long-term government bond minus the actual inflation rate over the following year) and international trade openness(\% of GDP, trade_open) and population density (popd). The choice of first four control variables (labor_prodg, dtot, inflation, long_real_r) closely follows IMF (2003) and OECD (2006). The inclusion of trade openness and population density as control variables for unemployment rates follows Bernal-Verdugo et. al.(2012). Felbermayr et. al. (2009) also finds that higher trade openness is causally associated to a lower structural rate of unemployment. Among the control 
variables, long real interest rate can at least partially capture aggregate demand shocks in business cycle.

$w_{i t}$ is the key variable of interest: Public social expenditure on unemployment benefit programs as a percentage of GDP, which may be endogenous. ${ }^{c_{i}}$ represent country fixed effects that capture unobserved country-specific determinants of unemployment, which may include some variables with high time constancy, such as national cultural (tradition) towards trade-off between leisure and work. $\theta_{t}$ is a fixed effect term for time, which captures global trend of some growth determinants that are common to all OECD countries, such as worldwide technology progress or global economic downturns or booms. Rothstein (2011) found that the "vast majority" of unemployment was due to "demand shocks" not "UI-induced supply reductions." This term $\theta_{t}$ can at least partially capture global demand shocks. The inclusion of this fixed effect and the control variable long_real_r can enable us to test whether Rothstein (2011)'s claim holds after controlling for demand shocks. ${ }^{u_{i t}}$ are idiosyncratic errors, which also absorb some time-varying omitted variables, such as home ownership (as pointed out by OECD (2006, p218), Home ownership is correlated with unemployment). Overall, this is a two-way fixed effect model for unbalanced panel data.

In all the models, public welfare expenditure on unemployment as a percentage of GDP (unem_exp) is the key variable of interest and possibly endogenous. To address this possible endogeneity, the approach of instrument variable (IV) estimation for panel data will be used. To establish validity of the IV used, IV strength test and Durbin-Wu-Hausman (DWH) Endogeneity test will be performed first to determine 1) if unem_exp is endogenous thus if IV estimation is necessary rather than LSDV estimation for panel data and 2) if IV is strong or weak. The details of these two tests are provided below in section 3.3. If DWH statistic is significant at $10 \%$ level but not at 5\% level, then both LSDV and IV estimation results will be presented for comparison. These two tests will be applied first for the tests on hypothesized disincentive effect and aggregate demand effect as explained in section 3.1 and then for the tests of full models that examine the economic impacts of unem_exp on unemployment outcomes (total, long-term and youth unemployment rates), labor participation rate and investment, the last of which is for testing the mechanism through which unem_exp impacts unemployment. 


\subsection{Test Endogeneity of public expenditure on unemployment}

It is likely that changes in unemployment induce changes in public welfare spending on unemployment (unem_exp). Unemployment may have both positive and negative impacts on public expenditure on unemployment benefits. For the first one, when unemployment rate is high, there are more claimants of /applicants for UI benefits and government is more likely to extend UI coverage time to alleviate the pain of the unemployed, as a result, the welfare expenditure on unemployment benefits as a percentage of GDP tends to rise. For the second one, higher unemployment is always accompanied by lower GDP growth, which is translated to lower tax income for government, which in turn may decrease welfare expenditure due to more scarce financial resources for re-allocation, one of which may be public expenditure on unemployment insurance provided by government. On the other hand, the effect of unemployment on UI expenditure may arise through another channel: higher unemployment and lower growth indicate bad economy, fewer job opportunities and lower income for working people, so it may be an incentive for heavier dependence on welfare benefits at the time of economic downturn, particularly unemployment insurance benefits. In short, there may exist reverse causality or feedback effect from unemployment rate to welfare expenditure on unemployment, which violates strict exogeneity assumption for the latter for Ordinary Least Square (OLS) estimation. If this assumption fails, the consistency of FE estimates on unem_exp is questionable. The Omitted variables, whose data is unavailable or unobservable to us, such as home ownership, may also be the source of endogeneity, as they may be correlated with unem_exp.

I apply classical Durbin-Wu-Hausman (DWH) test to check whether welfare spending on unemployment is endogenous in our regressions for unemployment rates thus whether IV estimation is necessary. Davidson and MacKinnon (1993) suggest an augmented regression test, which can easily be formed by including the residuals of each endogenous right-hand side variable, as a function of all exogenous variables and instrument variable(s), in a regression of the original model. The key requirement for this approach is that we can correctly identify all other strictly exogenous variables except suspicious endogenous variable(s) and we can find a valid IV, which has to be strongly correlated to welfare spending on unemployment but has no direct impact on unemployment outcomes(is uncorrelated with the unobservable error in regression). 
The choice of IV is the trickiest part of DWH test or IV regression. Beraldo et. al. (2009) used lagged values (up to three period) of possibly endogenous variables (health spending variables). These IVs are of course strongly correlated with endogenous variables but the exogeneity of them is highly suspicious. Using lagged values of possibly endogenous variables as instruments is never an appropriate way to ensure strictly exogeneity of the instruments for panel data. As Angrist \& Krueger (2001) pointed out, "One of the most mechanical and naive, yet common, approaches to the choice of instruments uses atheoretical and hard-to-assess assumptions about dynamic relationships to construct instruments from lagged variables in time series or panel data. The use of lagged endogenous variables...is problematic if the equation error or omitted variables are serially correlated". It is easy to verify that unemployment rate regressions always have residual errors serially correlated. So Beraldo et.al. (2009)'s approach of using one to three period lagged values of endogenous variable (health welfare expenditure) as instrument variables makes the exogeneity of these IVs very questionable.

The instrument variable (IV) chosen for public expenditure on unemployment (unem_exp) is road fatalities per million inhabitants (road) whose data comes from OECD Factbook 2010. Road fatality means any person killed immediately or dying within 30 days as a result of a road injury accident. Suicides involving the use of a road motor vehicle are excluded. The justification of the validity of this IV is elaborated as follows.

Death rate from road accidents presumably cannot affect unemployment and seems to have nothing to do with the omitted variables that affect unemployment rate, such as home ownership. However, this rate may be related to welfare spending in this way: in welfare states with higher welfare expenditure by government and more generous welfare benefit programs (including unemployment insurance program), people tend to have more leisure time and slower life pace. To prove this, a simple fixed effect model of hours on unem_exp is run where hours, as defined before, is average hours actually worked per year per person in employment. Table 4 shows that average annual hours actually worked per worker in OECD nations have strong negative association with public social expenditure on unemployment as a percentage of GDP. The estimate of unem_exp indicates that on average, in an OECD country, one percentage increase in welfare spending rate on unemployment (relative to GDP) leads to a reduction of working hours by about 68.2 hours in one year, or about 8.5 working days. This is a substantial effect. It implies that if Spain, whose average welfare spending rate on unemployment is $2.16 \%$ across $1980-2010$, 
decreases this rate to the level of USA for the same period, $0.33 \%$, an average Spanish worker would work longer by about 124.8 hours annually, nearly 16 working days!

Different patterns of time allocation between working and leisure lead to different life paces. The life pace is presumably closely related to the probability of traffic accidents. Through life pace, a country's road accident fatality is linked to its welfare level. The overall IV relevance test is performed by running a Least Squares Dummy Variable Regression (LSDV) of unem_exp on the IV (road) and other exogenous control variables. For example, to test the disincentive effect of unem_exp, two control variables are included: labor_prodg and wageg. Table 4 demonstrates that the IV road is a strong IV for unem_exp in this case (F statistic 25.28, p value 0), according to Sotck and Yogo (2005)'s thumb rule of F value exceeding 10 for one endogenous variable. It is also a very strong IV for testing the aggregate demand effect of unem_exp (F statistic 35.62, p value 0$)$.

The Durbin-Wu-Hausman (DWH) test can be performed as follows: we first regress unem_exp on all other explanatory variables in final regression, the instrument variable (road), dummy variables for each country and dummy variables for each year and obtain the residual, $\hat{v}_{2}$. Then we simply include $\hat{v}_{2}$ along with unity, all the explanatory variables in final model, either endogenous or exogenous, and dummy variables for nations and years in an OLS regression and obtain the $\mathrm{t}$ statistic on $\hat{v}_{2}$. The $\mathrm{p}$ values for the estimated parameters of $\hat{v}_{2}$ can indicate whether unem_exp is endogenous in the respective final regression. The last column of table 4 indicates that unem_exp is endogenous for the regression of hours ( pvalue $=0.0479$ ) but not endogenous for hh_consumr (pvalue $=0.177$ ) at 5\% significance level , so 2SLS estimation is only necessary for the regression of hours to ensure consistency of the estimate of unem_exp. For the regression of logypc, the DWH statistic of unem_exp is significant at 10\% level but insignificant at 5\% level ( $\mathrm{p}$ value $=0.0561$ ). Since this $\mathrm{p}$ value is between $5 \%$ and $10 \%$, both IV and LSDV regressions were run and results were compared.

\section{The Results}

Table 4 is a summary of econometric test results on the two effects of UI in theory. The result supports incentive effect of the theory, it indicates that public expenditure on unemployment has 
significant negative impact on equilibrium labor supply. Every percentage increase in unem_exp decreases average hours actually worked by about 68 , or about 8.5 business days. This proves hypothesized disincentive effect of unemployment insurance. However, unem_exp is found to have no significant effect on total consumption relative to GDP ( $\mathrm{hh}$ _consumr) ( $\mathrm{p}$ value $=0.642$ ), which disproves hypothesized aggregate demand effect of unemployment insurance. It is also shown that unem_exp has significant negative effect on log of per capita GDP ( $p$ value is 0.09 for OLS estimate and 0.009 for IV estimate), which is against the aggregate demand effect of unemployment insurance in theory.

As mentioned earlier, $\mathrm{CBO}$ estimates that that the policy of increasing aid to the unemployed would add 8 to 19 cumulative years of full-time-equivalent employment in 2010 and 2011 per million dollars of total budgetary cost. ${ }^{3}$ No detail about how this estimate was calculated was provided. Our econometric estimation result refutes the stimulative effect of welfare spending on employment, casting doubt on the validity of CBO's estimate. On the country, we find evidence suggesting that public expenditure on unemployment insurance may dampen aggregate demand and income and have a net negative impact on employment and economy.

Table 6 presents the results of the full model. To capture persistence of unemployment rate (or labor participation rate), one year lagged value of response variable is included and instrumented by two-year and three-year lagged values of response variable to correct for estimation inconsistency. Since DWH tests in table 5 show that public unemployment spending rate is not endogenous for all three unemployment rate measures but not endogenous for labor participation rate, we only include IVs for lagged dependent variable in the regressions for three unemployment rates but for the regression for labor participation, we add additional IV of road. Table 6 shows that public expenditure on unemployment has significantly positive effect on total unemployment rate and long-term unemployment rate but no significant effect on youth unemployment rate, the latter of which is consistent with the expectation that because the level of UI benefits depends upon previous earnings so UI has not much effect on youth unemployment. On average, each percentage point increase in welfare expenditure of unemployment benefit relative to GDP can increase total unemployment rate by 0.89 percentage

\footnotetext{
3 Policies for Increasing Economic Growth and Employment in 2010 and 2011, January 2010, CONGRESSIONAL BUDGET OFFICE, SECOND AND D STREETS, S.W., WASHINGTON, D.C. 20515, http://www.cbo.gov/sites/default/files/cbofiles/ftpdocs/108xx/doc10803/01-14-employment.pdf
} 
point. In other words, increasing unemployment welfare spending rate by one standard deviation raises total unemployment rate by 0.69 percentage point $(0.8878 * 0.7773)$. Is this effect large or small economically? The magnitude of this estimate (0.89) implies that during the period 19802010, if France, whose average welfare spending rate on unemployment is $1.61 \%$ for this period, could decrease this rate to the level of USA during this period, $0.33 \%$, the average total unemployment rate of France during this period could be decreased by 1.14 percentage point $(1.28 * 0.8878)$.

Similarly for all OECD nations, on average, each percentage point increase in unemployment welfare expenditure relative to GDP can increase long-term unemployment rate by 4.74 percentage point. In other words, increasing unemployment welfare spending rate by one standard deviation raises long-term unemployment rate by 3.68 percentage point $(4.7357 * 0.7773)$. If France could decrease its average welfare spending rate on unemployment across years 1998-2007 to the level of USA for this period, the average long-term unemployment rate of France in this period could be decreased by 6.06 percentage point $(1.28 * 4.7357)$. This means among unemployed people, the proportion of those who were unemployed for more than one year will be decreased by $6.06 \%$. Whether the magnitude of these two effects on total and long-term unemployment rates is attractive for policy makers to make policy change is up to the voters and politicians, but the economic effect of unemployment welfare spending on unemployment is definite: a significant positive effect on both the scale and duration of unemployment. Whether the magnitude of this effect has a substantial policy significance may be country-specific, however, the result gives strong evidence that the gaps in unemployment rates, particularly long-term unemployment rate between Europe and US in 1980s and 1990s may be partially explained by the differences in welfare spending on unemployment between USA and major western European countries. If combing other welfare expenditures, we expect the effect would be much larger.

The result on labor participation rate also supports our theoretical hypothesis: Unemployment welfare benefit can raise labor participation rate by preventing people from giving up job hunting. Every percentage point increase in unem_exp can increase labor participation rate by 1.29 percentage point. 
The theory on the two effects of UI only concerns the behavior of individuals. To examine the impact of public unemployment spending on the behavior of business, I also run a regression of it on investment rate with control variables including inflation, long real interest rate and trade openness. The estimate of the coefficient of unemployment spending rate is -2.07 and significant at $5 \%$ level. Every percentage point increase in public unemployment welfare expenditure relative to GDP can decrease capital formation as a percentage of GDP by over two percentage point. The mechanism of this decrease may be because higher unemployment insurance tax used to fund UI increases business cost thus dampening incentive to make more investment or because people have less incentive to save when welfare benefits from entitlement programs are available and therefore business is more difficult to finance investments due to lower saving rate. Further empirical work is worthy to explore which mechanism is the most important.

\section{The Robustness Check and Sensitivity Analysis}

To check the robustness of our estimation results to specification change, I re-run the model (3) with two control variables changed and one control variable added: labor productivity growth replaced by multi factor productivity growth rate and terms of trade shock by the lagged value of terms of trade change. The added control variable is net migration rate, which is defined as the difference between immigration into and emigration from the country during the year per 1000 inhabitants.

The motivation of adding this explanatory variable is during economic downturns, it is often the case that native workers blame high unemployment rate on immigrants. Simply put, they argue that immigrants are taking away jobs from natives. By adding net migration rate (migrate) as an additional control variable, we can test both whether the estimates of effects of public unemployment spending are robust to specification change and whether immigrants have any negative effect on unemployment measures.

The estimates of the coefficients for total and long-term unemployment rates in table 7 are very close to those in table 6 with only slight changes in magnitude. The magnitude is slightly higher for total unemployment rate (unemp) and slightly lower for long term unemployment rate. The estimate for unemp_exp is more significant now. With specification change, the effect of public unemployment spending rate on youth unemployment becomes significant at $5 \%$ level. We also note that all estimates for the coefficients of migration rate are significant and negative. Opposite 
to the widely heard accusation in press, immigrants are helping, rather than hindering, both the scale and duration of overall employment, which is consistent with the findings of Giovanni Peri (2010) and Vedder (1994).

\section{Discussion}

To answer the question "Is government's help for unemployed people helpful for the society?", empirical evidences are more important than theoretical debate. Most policies are likely to have opposing effects. The key to policy making is what the net effect is. Our econometric study clearly shows that higher public unemployment welfare expenditure leads to higher unemployment rate, both in number and in duration. The motivation of all welfare programs for unemployed people is undoubtedly noble: helping unemployed people, however, is government's help for unemployed people helpful for the society? Unfortunately the fact may not be a simple yes. As Anderson (2012) points out, "In the case of unemployment insurance, it is ironic that those whose political and policy fortunes have been most tied to the desire for a lower unemployment rate likely have contributed to a higher national unemployment rate through unfortunate choices".

The finding of this paper supports Barro (2012)'s argument that unemployment insurance is subsidizing unemployment and thus promoting unemployment. He argued that "the unemployment-insurance program involves a balance between compassion-providing for persons temporarily without work-and efficiency. The loss in efficiency results partly because the program subsidizes unemployment, causing insufficient job-search, job-acceptance and levels of employment. A further inefficiency concerns the distortions from the increases in taxes required to pay for the program." He further pointed out that "generous unemployment-insurance programs have been found to raise unemployment in many Western European countries in which unemployment rates have been far higher than the current U.S. rate. In Europe, the influence has worked particularly through increases in long-term unemployment." The Econometric estimation of this study indicates that every percentage point increase in unemployment entitlement expenditure relative to GDP can lead to 4.5 to 4.7 percentage point increase in long term unemployment rate, providing evidence to support Barro's claim. Barro provided a quantitative example to show the effect on US economy of the expansion of unemployment-insurance 
eligibility to as much as 99 weeks from the standard 26 weeks by American Recovery and Reinvestment Act passed by Congress in February 2009.

"To begin with a historical perspective, in the 1982 recession the peak unemployment rate of $10.8 \%$ in November-December 1982 corresponded to a mean duration of unemployment of 17.6 weeks and a share of long-term unemployment (those unemployed more than 26 weeks) of 20.4\%. Long-term unemployment peaked later, in July 1983, when the unemployment rate had fallen to $9.4 \%$. At that point, the mean duration of unemployment reached 21.2 weeks and the share of long-term unemployment was $24.5 \%$. These numbers are the highest observed in the post-World War II period until recently. Thus, we can think of previous recessions (including those in 2001, 1990-91 and before 1982) as featuring a mean duration of unemployment of less than 21 weeks and a share of long-term unemployment of less than $25 \%$.

These numbers provide a stark contrast with joblessness today. The peak unemployment rate of $10.1 \%$ in October 2009 corresponded to a mean duration of unemployment of 27.2 weeks and a share of long-term unemployment of $36 \%$. The duration of unemployment peaked (thus far) at 35.2 weeks in June 2010, when the share of long-term unemployment in the total reached a remarkable $46.2 \%$. These numbers are way above the ceilings of 21 weeks and $25 \%$ share applicable to previous post-World War II recessions. The dramatic expansion of unemploymentinsurance eligibility to 99 weeks is almost surely the culprit."

The data used in this paper has only covered public unemployment expenditure (\% of GDP) up to year 2007 for USA, so we cannot see the effect of this UI program extension from our data. However, the real data beyond the data used for econometric estimation in this paper validates the conclusion from this estimation, serving as a sort of quasi experiment as 2008 financial crisis was unexpected to most people.

Barro argued that one potential mechanism through which UI program impacts unemployment rate is "the distortions from the increases in taxes required to pay for the program". According to Rosen (2008), the cost to the employer in increased taxes used to fund UI program is less than the benefits that would be paid to the employee upon layoff. The firm in this instance believes that it is more cost effective to lay off the employee, causing more unemployment than under perfect experience rating. Consequently, firm will decrease investment and economy shrinks. This hypothesis is supported by our econometric finding in table 6 that every percentage point 
increase in unemployment public expenditure rate leads to 4.2 percentage point decrease in investment rate.

Our results show that the stimulative aggregate demand effect of public unemployment expenditure does not get support from the data while incentive effect hypothesized in theory has robust empirical support, only the impacts of UI program on supply side of labor market seems to be more important. However, the disincentive effect of UI program on business investment may also affect demand side of labor market negatively, worsening unemployment and economic growth. The help to individuals may not always be aligned with the interests of the society, policy makers need to take this into account to strike a balance for decisions involving economic trade-off.

\section{Conclusion}

Using panel data of public unemployment expenditure as a percentage of GDP of 34 OECD nations across year 1980-2010, I explore the effect of this ratio on three unemployment outcomes: total unemployment rate, long-term unemployment rate and youth unemployment, as well as labor participation rate and investment rate. After taking into account potential endogeneity of this ratio using Durbin-Wu-Hausman test, I find the data does not support the hypothesized aggregate demand effect of unemployment insurance (UI) expenditure in theory but gives strong support for hypothesized disincentive effect in theory. The estimates indicate that every percentage point increase in public unemployment welfare expenditure relative to GDP leads to 0.9 to 1.1 percentage point increase in total unemployment rate and 4.5 to 4.7 percentage point increase in long term unemployment rate. The distortionary effect of UI program on business is also verified by an estimate that every percentage point increase in this unemployment spending rate is associated with about 2.1 percentage point decrease in investment rate. 
Table 1 The variable definitions, data sources and time coverage of data

\begin{tabular}{|c|c|c|c|}
\hline variable & Definition & Data source & Time coverage \\
\hline dtot & $\begin{array}{l}\text { Percentage change in the terms of trade weighted by the } \\
\text { trade openness of the country }\end{array}$ & WDI2010 & $1981-2010$ \\
\hline Unem_exp & $\begin{array}{l}\text { Public social expenditure on unemployment program as a } \\
\text { percentage of GDP }\end{array}$ & OECD (2010) & $1960-2010$ \\
\hline & Average hours actually worked: & & \\
\hline hours & Hours per year per person in employment & OECD Factbook 2010 & $1980-2012$ \\
\hline inflation & $\begin{array}{l}\text { Inflation rate: Consumer price indices (CPI): annual growth in } \\
\text { percentage }\end{array}$ & OECD Factbook 2010 & $1955-2008$ \\
\hline invrate & $\begin{array}{l}\text { Investment rate: the share of total GDP that is devoted to } \\
\text { investment in fixed assets }\end{array}$ & OECD Factbook 2010 & $1976-2006$ \\
\hline Labor_prodg & Labor productivity growth rate & OECD StatExtracts & $1990-2011$ \\
\hline & $\begin{array}{l}\text { long real interest rate :The nominal returns on long-term } \\
\text { government bond minus the actual inflation rate over the }\end{array}$ & & \\
\hline Long_real_r & following year & OECD (2012) & $1955-2008$ \\
\hline & $\begin{array}{l}\text { Long unemployment rate: proportion of people who have } \\
\text { been unemployed for } 12 \text { months or more among all }\end{array}$ & & \\
\hline Long_unem2 & unemployed & WDI2010 & $1980-2010$ \\
\hline mf_prodg & Multi-factor Productivity growth & OECD StatExtract & $1985-2010$ \\
\hline & $\begin{array}{l}\text { Net migration rate: The difference between immigration into } \\
\text { and emigration from the area during the year per } 1000\end{array}$ & & \\
\hline migrate & inhabitants & OECD Factbook 2010 & $1955-2008$ \\
\hline popd & Population density (people per square km of land area) & WDI2010 & $1961-2010$ \\
\hline road & Road fatalities Per million inhabitants & OECD Factbook 2010 & $1990-2008$ \\
\hline Trade_open & International trade openness (\% of GDP) & WDI2010 & $1960-2008$ \\
\hline unemp & Unemployment rate & OECD Factbook & $1955-2010$ \\
\hline & Proportion of seats held by women in national parliaments & & \\
\hline women & $(\%)$ & WDI2010 & $1990-2011$ \\
\hline hh_consumr & household consumption rate (\% of GDP) & WDI2010 & $1966-2005$ \\
\hline logypc & Log of per capita GDP & WDI2010 & $1975-2005$ \\
\hline Youth_unem2 & Youth unemployment rate: \% of youth labour force (15-24) & WDI2010 & $1980-2010$ \\
\hline wageg & $\begin{array}{l}\text { Wage growth rate: annual growth rate of labor compensation } \\
\text { per labor unit }\end{array}$ & OECD StatExtracts & 1971-2008 \\
\hline
\end{tabular}

WDI2010: World Development Indicator 2010 Edition, World Bank. 
Table 2 Summary Statistics for variables used in the models

\begin{tabular}{llllll}
\hline Variable & $\mathrm{N}$ & Mean & Std Dev & Minimum & Maximum \\
\hline unemp & 989 & 6.5237 & 3.7334 & 0.1 & 20.1494 \\
long_unem2 & 817 & 32.4050 & 17.8792 & 0.3 & 76.2 \\
youth_unem2 & 889 & 15.5267 & 8.2267 & 2.6 & 43.9 \\
unem_exp & 322 & 0.9078 & 0.7773 & 0 & 3.4 \\
labor_prodg & 694 & 1.9347 & 2.4922 & -11.6 & 17.5 \\
mf_prodg & 456 & 1.2140 & 1.7142 & -7.6 & 7.6 \\
dtot & 688 & 0.0198 & 1.8160 & -10.2448 & 22.5451 \\
inflation & 1513 & 12.1580 & 47.3427 & -3.5 & 1281.4 \\
trade_open & 1187 & 34.8219 & 21.5213 & 4 & 160.5 \\
popd & 1622 & 115.4203 & 113.2750 & 1.3646 & 508.8568 \\
invrate & 1193 & 22.8427 & 4.1450 & 14.8 & 37.5 \\
Long_real_r & 774 & 3.182571 & 3.1332 & -21.17 & 14.63 \\
migrate & 1512 & 1.6707 & 4.4158 & -23.1 & 40.3 \\
hh_consumr & 1170 & 58.5843 & 6.937004 & 39.70264 & 79.74503 \\
wageg & 784 & 8.436097 & 10.69219 & -2.5 & 101.8 \\
hours & 921 & 1821.605 & 237.4955 & 1334 & 2923 \\
logypc & 365 & 10.06548 & .409891 & 9.051459 & 11.08429 \\
road & 637 & 115.2418 & 46.6745 & 37 & 316 \\
\hline
\end{tabular}

Table 3 Correlation Matrix of Unemployment Rates and Welfare Measures

\begin{tabular}{|c|c|c|c|c|c|c|c|c|c|}
\hline & unemp & long_u 2 & youth_ 2 & labor_ $\mathrm{i}$ & invrate & hours & hh_con $\sim r$ & logypc & unem_exp \\
\hline unemp & 1 & & & & & & & & \\
\hline long_unem2 & $0.5777^{* * *}$ & 1 & & & & & & & \\
\hline youth_unem2 & $0.8824 * * *$ & $0.5782 * * *$ & 1 & & & & & & \\
\hline labor_parti & $-0.4231 * * *$ & $-0.6018^{* * *}$ & $-0.5113 * * *$ & 1 & & & & & \\
\hline invrate & $-0.3347 * * *$ & $-0.0803 * *$ & $-0.231 * * *$ & 0.0641 & 1 & & & & \\
\hline hours & 0.0172 & $-0.0714^{*}$ & $0.1028^{* * *}$ & $-0.1973 * * *$ & $0.407 * * *$ & 1 & & & \\
\hline hh_consumr & $0.2842 * * *$ & $0.176^{* * *}$ & $0.3 * * *$ & $-0.1723 * * *$ & $-0.2097 * * *$ & $0.3263 * * *$ & 1 & & \\
\hline logypc & $-0.4944 * * *$ & $-0.2868 * * *$ & $-0.4127 * * *$ & $0.4102 * * *$ & $-0.1869 * * *$ & $-0.6149 * * *$ & $-0.5717 * * *$ & 1 & \\
\hline unem_exp & $0.1135^{*}$ & $0.1535^{* * *}$ & -0.006 & -0.0284 & $-0.2078 * * *$ & $-0.5372 * * *$ & $-0.3515^{* * *}$ & $0.312^{* * *}$ & 1 \\
\hline
\end{tabular}

$*, * *, * * *$ denote significance at 10 percent, 5 percent, and 1 percent, respectively. 
Table 4 The results of tests for disincentive effect and aggregate demand effect of UI

\begin{tabular}{|c|c|c|c|c|c|c|c|c|c|c|}
\hline Test effect & Model & $\begin{array}{l}\text { Dependent } \\
\text { variable }\end{array}$ & $\begin{array}{l}\text { Independent } \\
\text { variable }\end{array}$ & coefficient & $\begin{array}{l}\text { Standard } \\
\text { Error }\end{array}$ & $\begin{array}{l}P \text { value } \\
\text { for SE }\end{array}$ & $\begin{array}{l}\text { R- } \\
\text { square }\end{array}$ & $\mathrm{N}$ & $\begin{array}{l}\text { IV strength } \\
\text { F statistic }\end{array}$ & DWH statistic \\
\hline & LSDV & hours & Unem_exp & -24.7977 & 7.37 & 0.001 & 0.99 & 309 & & \\
\hline & LSDV & road & hours & 0.0576 & 0.0176 & 0.001 & 0.88 & 574 & & \\
\hline & LSDV & road & Unem_exp & -19.054 & 3.7118 & 0.000 & 0.91 & 322 & & \\
\hline \multirow[t]{11}{*}{$\begin{array}{l}\text { Disincentive } \\
\text { effect }\end{array}$} & LSDV & Unem exp & road & $-0.005 * * *$ & 0.001 & 0.000 & 0.95 & 274 & $25.28(0)$ & \\
\hline & & & labor_prodg & 0.0058 & 0.0069 & 0.40 & & & & \\
\hline & & & wageg & -0.005 & 0.0031 & 0.874 & & & & \\
\hline & LSDV & hours & Unem_exp & -68.2635 & 23.5246 & 0.004 & 0.99 & 264 & & \\
\hline & & & wageg & -1.4713 & 0.43315 & 0.001 & & & & \\
\hline & & & labor_prodg & -1.6904 & 0.8530 & 0.049 & & & & \\
\hline & & & Residual from & & & & & & & \\
\hline & & & IV test & $49.2408 * *$ & 24.7551 & 0.048 & & & & $3.96(0.0479)$ \\
\hline & IV & hours & Unem_exp & -68.174 & 23.4735 & 0.004 & 0.99 & 264 & & \\
\hline & & & wageg & -1.3681 & 0.4395 & 0.002 & & & & \\
\hline & & & labor_prodg & -1.6002 & 0.8603 & 0.063 & & & & \\
\hline \multirow{29}{*}{$\begin{array}{l}\text { Aggregate } \\
\text { demand } \\
\text { effect }\end{array}$} & & & & & & & & & & \\
\hline & LSDV & Unem_exp & road & $-.0075^{* * *}$ & .0013 & 0.000 & 0.96 & 230 & $35.62(0)$ & \\
\hline & & & inflation & -.0308 & .0161 & 0.057 & & & & \\
\hline & & & wageg & -.0263 & .0091 & 0.004 & & & & \\
\hline & & & long_real_r & 0.007 & .0144 & 0.630 & & & & \\
\hline & LSDV & hh_consumr & unem_exp & -1.3169 & 1.297 & 0.312 & 0.98 & 180 & & \\
\hline & & & wageg & -.0984 & 0.069 & 0.156 & & & & \\
\hline & & & long_real_r & .1592 & .1033 & 0.126 & & & & \\
\hline & & & inflation & -.1661 & .1168 & 0.157 & & & & \\
\hline & & & Residual from & & & & & & & \\
\hline & & & IV test & 1.900 & 1.4011 & 0.177 & & & & $1.84(0.177)$ \\
\hline & LSDV & hh_consumr & unem_exp & .2651 & .5697 & 0.642 & 0.98 & 180 & & \\
\hline & & & wageg & -.0628 & 0.064 & 0.328 & & & & \\
\hline & & & long_real_r & .1548 & .1036 & 0.137 & & & & \\
\hline & & & inflation & -.1260 & .1133 & 0.268 & & & & \\
\hline & LSDV & logypc & unem_exp & $-.0834 * *$ & .0342 & 0.016 & 0.99 & 188 & & \\
\hline & & & wageg & -.0048 & .0019 & 0.013 & & & & \\
\hline & & & long_real_r & -.0068 & .0025 & 0.012 & & & & \\
\hline & & & inflation & -.0077 & .0028 & 0.007 & & & & \\
\hline & & & Residual from & & & & & & & \\
\hline & & & IV test & $.0729 *$ & .0379 & 0.056 & & & & $3.71(0.0561)$ \\
\hline & OLS & logypc & unem_exp & $-.0227 *$ & .0133 & 0.090 & 0.99 & 188 & & \\
\hline & & & wageg & -.0032 & .0017 & 0.070 & & & & \\
\hline & & & long_real_r & -.0074 & .0026 & 0.006 & & & & \\
\hline & & & inflation & -.0064 & .0029 & 0.030 & & & & \\
\hline & IV & logypc & unem_exp & $-.0755^{* * *}$ & 0.029 & 0.009 & 0.99 & 188 & & \\
\hline & & & wageg & -.0038 & .0017 & 0.023 & & & & \\
\hline & & & long_real_r & -.0064 & .0025 & 0.012 & & & & \\
\hline & & & inflation & -.0077 & .0028 & 0.007 & & & & \\
\hline
\end{tabular}

All the regressions include both time and country fixed effects.

Within parenthesis is $\mathrm{p}$ value.

$*, * *, * * *$ denote significance at 10 percent, 5 percent, and 1 percent, respectively. 
Table 5 The results of IV strength test \& DWH endogeneity test

\begin{tabular}{|c|c|c|c|c|c|c|c|c|c|}
\hline Test & $\begin{array}{l}\text { Dependent } \\
\text { variable }\end{array}$ & $\begin{array}{l}\text { Independent } \\
\text { variable }\end{array}$ & coefficient & $\begin{array}{l}\text { Standard } \\
\text { Error }\end{array}$ & $\begin{array}{l}P \text { value } \\
\text { for SE }\end{array}$ & $\begin{array}{l}\text { R- } \\
\text { square }\end{array}$ & $\mathrm{N}$ & $\begin{array}{l}\text { IV } \\
\text { strength } \\
\text { F statistic }\end{array}$ & DWH statistic \\
\hline \multirow[t]{7}{*}{ IV strength } & Unem_exp & road & -0.0053 & 0.0012 & 0.000 & 0.96 & 230 & 18.07(0) & \\
\hline & & long_real_r & 0.0110 & 0.0136 & 0.421 & & & & \\
\hline & & labor_prodg & 0.0173 & 0.0099 & 0.082 & & & & \\
\hline & & trade_open & -0.0050 & 0.0049 & 0.304 & & & & \\
\hline & & popd & 0.0217 & 0.0070 & 0.002 & & & & \\
\hline & & inflation & -0.0314 & 0.0149 & 0.036 & & & & \\
\hline & & dtot & 0.0020 & 0.0087 & 0.815 & & & & \\
\hline \multicolumn{10}{|l|}{ DWH } \\
\hline \multirow[t]{5}{*}{ Endogeneity } & unemp & & & & & & & & $2.30(0.131)$ \\
\hline & Long_unem2 & & & & & & & & $0.94(0.3323)$ \\
\hline & Youth_unem2 & & & & & & & & $1.81(0.1803)$ \\
\hline & Labor_parti & & & & & & & & $15.07(0.001)$ \\
\hline & invrate & & & & & & & & $2.93(0.0886)$ \\
\hline
\end{tabular}

DWH endogeneity test for health outcome and labor participation is a regression of one unemployment measure (one of unemp, long_unem2, youth_unem2) on unem_exp, long_real_r, labor_prodg, trade_open, popd, inflation, dtot, dummy variables for each country, dummy variables for each year and the residual from the IV strength test.

DWH endogeneity test for invrate is a regression of invrateon unem_exp, inflation, long_real_r $r$ trade_open and the residual from the IV strength test.

All the regressions include both time and country fixed effects.

$*, * * * * *$ denote significance at 10 percent, 5 percent, and 1 percent, respectively.

LSDV=Least Square Dummy Variable estimation model for panel data; IV= Instrumental Variable estimation for panel data. 
Table 6 The results of Final Models for Three Unemployment Rates, labor participation rate and investment rate

\begin{tabular}{|c|c|c|c|c|c|c|}
\hline & unemp & long_unem2 & Youth_unem2 & Labor_parti & invrate & invrate \\
\hline $\begin{array}{l}\text { One year lagged } \\
\text { value of } \\
\text { response } \\
\text { variable }\end{array}$ & $\begin{array}{l}0.7914 \\
(0.0819) * * *\end{array}$ & $0.6495(0.0777)^{* * *}$ & $\begin{array}{l}0.8389 \\
(0.0572) * * *\end{array}$ & $0.8474(0.0553)^{* * *}$ & & \\
\hline Unem_exp & $0.8878(0.3790)^{* *}$ & $4.7357(1.0252) * * *$ & $1.3416(0.8727)$ & $1.2938(0.4793)^{* * *}$ & $-2.0673(0.8092) * *$ & $-4.2209(1.3005) * * *$ \\
\hline Labor_prodg & $0.0193(0.0341)$ & $0.0880(1.0252)$ & $0.0407(0.0781)$ & $-0.0633(0.0331)^{* *}$ & & \\
\hline dtot & $0.0091(0.0212)$ & $-0.0370(0.0687)$ & $0.0231(0.0405)$ & $-0.0001(0.0226)$ & & \\
\hline inflation & $\begin{array}{l}0.1760 \\
(0.0472)^{* * *}\end{array}$ & $\begin{array}{l}-0.5798 \\
(0.1851)^{* * *}\end{array}$ & $\begin{array}{l}0.3628 \\
(0.0959)^{* * *}\end{array}$ & $0.1501(0.0393)^{* * *}$ & $0.2263(0.2239)$ & $.1569(.1174)$ \\
\hline Long_real_r & $\begin{array}{l}0.1558 \\
(0.0586)^{* * *}\end{array}$ & $-0.0694(0.2075)$ & $\begin{array}{l}0.3873 \\
(0.1291)^{* * *}\end{array}$ & $-0.0728(0.0407)^{*}$ & $-0.3618(0.1739)^{* *}$ & $-.3323(0.10)^{* * *}$ \\
\hline Trade_open & $-0.0527(0.0270)^{* *}$ & $0.1055(0.0720)$ & $-0.1200(0.0569)^{* *}$ & $-0.0085(0.0156)^{* * *}$ & $\begin{array}{l}- \\
0.1833(0.0419) * * *\end{array}$ & $-.1691(.0304)^{* * *}$ \\
\hline popd & $0.0482(0.0267)^{*}$ & $-0.1084(0.1277)$ & $0.0989(0.0676)$ & $-0.0164(0.0280)$ & & \\
\hline model & IV & IV & IV & IV & LSDV & IV \\
\hline $\begin{array}{l}\text { Instrument } \\
\text { variable }\end{array}$ & $\begin{array}{l}\text { Two-year and } \\
\text { three-year lagged } \\
\text { values of response } \\
\text { variable }\end{array}$ & $\begin{array}{l}\text { Two-year and } \\
\text { three-year lagged } \\
\text { values of response } \\
\text { variable }\end{array}$ & $\begin{array}{l}\text { Two-year and } \\
\text { three-year lagged } \\
\text { values of response } \\
\text { variable }\end{array}$ & $\begin{array}{l}\text { Two-year and three- } \\
\text { year lagged values } \\
\text { of response variable } \\
\text { + road }\end{array}$ & $\begin{array}{l}\text { Two-year and } \\
\text { three-year lagged } \\
\text { values of response } \\
\text { variable }\end{array}$ & $\begin{array}{l}\text { Two-year and } \\
\text { three-year lagged } \\
\text { values of response } \\
\text { variable + road }\end{array}$ \\
\hline R square & 0.9727 & 0.9840 & 0.9704 & 0.9632 & 0.8451 & 0.8315 \\
\hline $\mathrm{N}$ & 230 & 216 & 230 & 375 & 254 & 254 \\
\hline
\end{tabular}

Robust clustered standard errors in parenthesis.

$*, * *, * * *$ denote significance at 10 percent, 5 percent, and 1 percent, respectively.

All the regressions include fixed effects of both year and country.

LSDV=Least Square Dummy Variable estimation model for panel data; IV= Instrumental Variable estimation for panel data. 
Table 7 Sensitivity analysis

\begin{tabular}{|c|c|c|c|c|}
\hline & unemp & long_unem2 & Youth_unem2 & Labor_parti \\
\hline $\begin{array}{l}\text { One year lagged } \\
\text { value of response } \\
\text { variable }\end{array}$ & $0.5743(0.1094)^{* * *}$ & $.6592(.0779)^{* * *}$ & $.6490(.0869)^{* * *}$ & $.8153(.1008)^{* * *}$ \\
\hline Unem_exp & $1.1396(0.3283)^{* * *}$ & $4.4957(1.0364)^{* * *}$ & $1.7309(.7404)^{* *}$ & $.8589(.4984)^{*}$ \\
\hline migrate & $-0.0655(0.0260)^{* *}$ & $-.3928(.1417)^{* * *}$ & $-.1030(.0568)^{*}$ & $.07186(.0184)^{* * *}$ \\
\hline mf_prodg & $-0.0457(0.0641)$ & $-.1049(.1875)$ & $-.1018(.118)$ & $-.0232(.0403)$ \\
\hline Idtot & $0.0517(0.0628)$ & $-.4962(.356)$ & $.125(.1476)$ & $.1111(0.04)^{* * *}$ \\
\hline inflation & $-0.0808(0.0640)$ & $-1.0708(.3867)^{* * *}$ & $-.04(.1837)$ & $.1019(.0552)^{*}$ \\
\hline Long_real_r & $0.0136(0.0616)$ & $-.92101(.3007)^{* * *}$ & $-.049(.179)$ & $-.1575(.0531)^{* * *}$ \\
\hline Trade_open & 0.0209 (0.0172) & $.1232(.0956)$ & $.0423(.046)$ & $-.0062(.0253)$ \\
\hline popd & $-0.0025(0.0310)^{*}$ & $-.1166(.1156)$ & $-.0532(.0849)$ & $.0145(0.046)$ \\
\hline $\begin{array}{l}\text { DWH statistic for } \\
\text { unem_exp }\end{array}$ & $0.02(0.876)$ & $0.40(0.5294)$ & $1.17(0.2812)$ & $6.69(0.0109)$ \\
\hline model & IV & IV & IV & IV \\
\hline Instrument variable & $\begin{array}{l}\text { Two-year and three- } \\
\text { year lagged values of } \\
\text { response variable }\end{array}$ & $\begin{array}{l}\text { Two-year and } \\
\text { three-year lagged } \\
\text { values of response } \\
\text { variable }\end{array}$ & $\begin{array}{l}\text { Two-year and } \\
\text { three-year lagged } \\
\text { values of response } \\
\text { variable }\end{array}$ & $\begin{array}{l}\text { Two-year and } \\
\text { three-year lagged } \\
\text { values of response } \\
\text { variable + road }\end{array}$ \\
\hline $\mathrm{R}$ square & 0.9593 & 0.98 & 0.96 & 0.99 \\
\hline $\mathrm{N}$ & 151 & 138 & 151 & 151 \\
\hline
\end{tabular}

For upper panel, robust clustered standard errors are in parenthesis; For bottom panel, $\mathrm{p}$ values are in parenthesis. $*, * *, * * *$ denote significance at 10 percent, 5 percent, and 1 percent, respectively.

All the regressions include fixed effects of both year and country. 


\section{References}

Angrist, Joshua D. ; Krueger, Alan B. (2001) "Instrumental Variables and the Search for Identification: From Supply and Demand to Natural Experiments," Journal of Economic Perspectives, American Economic Association, vol. 15(4), pages 69-85, Fall.

Barro, Robert (2012), The Folly of Subsidizing Unemployment, Wall Street Journal, August 302010 http://online.wsj.com/article/SB10001424052748703959704575454431457720188.html

Beraldo, Sergio; Montolio, Daniel; Turati Gilberto (2009), Healthy, educated and wealthy: A primer on the impact of public and private welfare expenditures on economic growth, Journal of Socio-Economics 38 (2009) 946-956

Bernal-Verdugo, Lorenzo E. ; Furceri, Davide; Guillaume, Dominique (2012), Labor Market Flexibility and Unemployment: New Empirical Evidence of Static and Dynamic Effects, IMF Working Paper WP/12/64, March 2012

Card, David \& Levine, Phillip B., (2000). "Extended benefits and the duration of UI spells: evidence from the New Jersey extended benefit program," Journal of Public Economics, 2000, v78(1-2,Oct), 107-138.

CBO (2010), Policies for Increasing Economic Growth and Employment in 2010 and 2011, January 2010, Congressional Budget Office, Second And D Streets, S.W., Washington, D.C. 20515,

http://www.cbo.gov/sites/default/files/cbofiles/ftpdocs/108xx/doc10803/01-14-employment.pdf

CBO (2012), Unemployment Insurance in the Wake of the Recent Recession, Nov. 2012, Congressional Budget Office, Second And D Streets, S.W., Washington, D.C. 20515

http://www.cbo.gov/sites/default/files/cbofiles/attachments/11-28-UnemploymentInsurance_0.pdf

Davidson, R. and J. G. MacKinnon (1993), Estimation and Inference in Econometrics. New York: Oxford University Press.

Felbermayr, Gabriel; Prat, Julienne; Schmerer,Hans-Jörg (2009), Trade and Unemployment: What Do the Data Say? IZA Discussion Paper No. 4184, May 2009, http://ftp.iza.org/dp4184.pdf

Fredriksson, P. \& B. Holmlund (2006), Improving Incentives in Unemployment Insurance: A Review of Recent Research, Journal of Economic Surveys, 21, 357-386.

Giovanni Peri (2010), “The Effect of Immigrants on U.S. Employment and Productivity,” FRBSF Economic Letter, 2010 26, August 30, 2010.

Holmlund, B. (1998), Unemployment Insurance in Theory and in Practice, Scandinavian Journal of Economics, 100, 113141.

Howell, David R.; Azizoglu, Bert M. (2011), Unemployment Benefits and Work Incentives: The U.S. Labor Market in the Great Recession (revised), Political Economy Research Institute, 3/21/2011, Oxford Review of Economic Policy, volume 27, no. 2 (summer 2011).

IMF (2003), UNEMPLOYMENT AND LABOR MARKET INSTITUTIONS: WHY REFORMS PAY OFF, Chapter IV.

Rothstein, Jesse (2011), Unemployment Insurance and Job Search in the Great Recession, NBER Working Paper No. 17534, Issued in October 2011

Katz, L. \& B. Meyer (1990), The Impact of the Potential Duration of Unemployment Benefits on the Duration of Unemployment, Journal of Public Economics, 41, 45-72.

Krueger, A. \& B. Meyer (2002), The Labor Supply Effects of Social Insurance”, in A. Auerbach \& M. Feldstein (eds) Handbook of Public Economics, Vol. 4, North- Holland, Amsterdam, 2327-2392.

Lalive, R. \& J. Zweimüller (2004), Benefit Entitlement and Unemployment Duration: The Role of Policy Endogeneity, Journal of Public Economics, 88, 2587-2616. 
OECD (2006): OECD Employment Outlook: Boosting Jobs and Incomes, ISBN 92-64-02384-4, C OECD 2006

OECD (2010): Social issues: Key tables from OECD - ISSN 2074-3904 - C OECD 2010, Source: Social expenditure: Aggregated data, OECD Social Expenditure Statistics (database)

OECD (2012), "Long-term interest rates", Economics: Key Tables from OECD, No. 10. doi: 10.1787/lti-table-2012-11-en Vedder, Richard (1994), “Immigration Doesn’t Displace Natives,” Wall Street Journal, March 28, 1994.

Rosen, Harvey S. (2008), Public Finance. New York, New York: McGraw-Hill/Irvin. pp. 292. ISBN 978-0-07-351128-3.

Stock, James H. and Motohiro Yogo (2005), “Testing for Weak Instruments in Linear IV Regression.” Ch. 5 in J.H. Stock and D.W.K. Andrews (eds), Identification and Inference for Econometric Models: Essays in Honor of Thomas J.

Rothenberg, Cambridge University Press. Originally published 2001 as NBER Technical Working Paper No. 284;

Anderson, Stuart (2010), Let's Not Blame Immigrants for High Unemployment Rates, Immigration Reform Bulletin , September 2012

Valletta, Rob ; Kuang, Katherine (2010), Extended Unemployment and UI Benefits, FRBSF ECONOMIC LETTER, 2010-12 April 19, 2010 , http://www.frbsf.org/publications/economics/letter/2010/el2010-12.pdf 